\title{
TOURISTS AND LOCAL COMMUNITY OF THE CASE STUDY AQABA SPECIAL ECONOMIC ZONE AUTHORITY (ASEZA)
}

\author{
Omar A.A. JAWABREH* \\ The University of Jordan, Faculty of Tourism and Hospitality, Department of Hotel Management, Jordan, e-mail: o.jawabreh@ju.edu.jo
}

\begin{abstract}
Citation: Jawabreh, O.A.A. (2021). TOURISTS AND LOCAL COMMUNITY OF THE CASE STUDY AQABA SPECIAL ECONOMIC ZONE AUTHORITY (ASEZA). GeoJournal of Tourism and Geosites, 35(2), 490-498. https://doi.org/10.30892/gtg.35229-676
\end{abstract}

\begin{abstract}
The research aims to examine the shared effect of tourism in Aqaba and the Jordanian host culture. Despite the presence of preferences and developments in tourism opportunities and problems, despite the fact that these circumstances are marked by, uncertainty, and personal shifts, the local community's behaviour and attitudes towards the tourism industry are highly dependent on them. A questionnaire was circulated to a group of (1200) people living in Aqaba to accomplish this goal. From 1/1/2019 until $30 / 12 / 2019$, the allocation and restitution took one year, taking into account the low and high tourism seasons. In order to assess the most important facets of the socio-cultural and economic impacts of tourism in these regions, the questionnaire was circulated to the survey participants in order to measure attitudes towards tourism. This analysis is an exploratory, empirical study that follows the process of obtaining and reviewing knowledge to draw conclusions. To assess the degree of significance for the study questions, the researchers used the arithmetic mean, standard deviation, T-test and ANOVA test. The findings revealed that the economic sub-scale was the highest degree of attitudes towards tourism, while the lowest was the social sub-scale. This research provides a better understanding of the social and cultural effects of tourism and the host culture in Jordan, in order to establish a holistic growth of sustainable tourism in Aqaba. It is possible to submit and further test the new model at another destination in Jordan.
\end{abstract}

Key words: attitude, host community, mutual impact, Aqaba Special Economic Zone Authority (ASEZA)

$* * * * * *$

\section{INTRODUCTION}

Tourism has been a social, cultural and economic event for both the tourist and the host. It is understood that the most enticing tourist draw for tourists is proximity to various areas of the country, different lifestyles and new cultures.In this context, the current study aims to understand the expectations of residents about the impacts of tourism in Aqaba, Jordan, namely: effects, social impact, cultural impact and economic impact, and to examine, if any, the variations in the perceptions of residents across various citizen groups. The literature review indicates that several observational tourism research have looked at the effects of the industry on local community development (Chigora et al., 2020; Harilal and Tichaawa, 2020; Alfandi, 2020). But these studies are uncommon and much less use multidimensional community property assessments. An ideal geographic position in the middle of the Red Sea between Asia and Africa, has rendered the port of Aqaba significant since time immemorial. Elath, which was once known as Elā in both as well as Ailah and in other languages. It was strategically located, as well as the close proximity to copper mines, during the Chalcolithic era. At the time of the Byzantine Empire's reign and afterwards, the area around the city of Aqaba was called "Aila;" the word Aqaba is post-era is Latin. Arabs became victorious in the at the Battle of Aqaba in the movie Lawrence of Arabia because of this rebellion. Luxury resorts in the Tala Bay provide facilities $20 \mathrm{~km}$ south of here cater to those who arrive for relaxation as well as scuba training. However, this facility also takes advantage of its desert position by offering programs including sand art therapy and sand art therapy. One of the most common places to use for relaxation is the Turkish bath (hamam) constructed in $306 \mathrm{AD}$, in which the locals and tourists alike enjoy soaking in warm water after a long day in the sun (Jawabreh, 2017).

The new meta-study (focusing on poverty) alleviation at the local level and gathering multi-dimensional data depends on expectations of impacts by neighborhood and tourism operators. In particular, they argued for local effect studies gather primary data through various approaches and the use of multi-dimensional growth measures. Tourism analyses and their relationship with indigenous communities appear to use qualitative methods, as well as secondary analyzes of geographical, economic and ecological evidence introduced since the start of tourism ventures. There are little, often suspect, community benefits from tourism that seem to disapprove of resources and influence in the political-economic process of interaction between the two countries (ÇavuĢoğlu et al., 2020; Gorochnaya et al., 2021; Maaiah and Wouhoush, 2020; Hermann et al., 2020). The environmental effect of tourism is possible, since tourism is always developed utilizing natural resources in vulnerable settings (Zeng and Ryan, 2012). The possible negative and positive impacts of any tourism growth activity on the local ecosystem are associated with (Smeral, 2015). Nevertheless, the negative influence of tourism outweighs its positive effects as it leads to two main phenomena, namely contamination and the loss of natural resources (Peng and Yuan, 2019). In addition, tourism growth is assumed to have a direct influence on the ecosystem as it leads to an improvement in the production of visitor facilities and amenities. As a core concept of the theory of social exchange, the economic reliance of people on tourism has a strong influence on their understanding of the consequences of tourism.

\footnotetext{
* Corresponding author
} 
Empirically (Lekgau and Tichaawa, 2020), the economic vulnerability of citizens in the tourism sector has often had an effect on their perception of the effects. It also means that people are more likely to establish positive views towards it if they profit from tourism partnerships. In other terms, people working in tourism-related occupations are more prone to establish positive perceptions and perceptions about their benefits and to have less worry about the detrimental effects of tourism development. Many other reports, such as Tohmo, 2018; Garidzira and Pasara, 2020; Li et al., 2005; Hwang and Lee, 2015; Song et al., 2012; Gozgor and Ongan, 2017; Song and Li, 2008, reported similar facts. It may also be concluded that the larger the economic reliance on tourism, the more likely it is for people to see the beneficial results of tourism.

The purpose of this study is to clarify the social and cultural effects of tourism and the host community in Jordan. In order to create a healthy, sustainable growth of tourism in Aqaba, we should recognize the attitudes of the local community towards the tourism process and compare the social perception of the city with the importance of its social and cultural influence of tourism. Jordan's only port on the Gulf of Aqaboun is in the whole world is Aqaba.

\section{LITERATURE REVIEW}

Perception of tourism impact on the local community is one of the most researched subjects in tourism. Many studies have discussed the economic, social, cultural, and environmental impacts of tourism development as perceived by community negative economic impacts, such as increased living costs, speculation, and tax burdens, are perceived by residents. Perceived adverse social and cultural impacts include increases in divorce rates, alcoholism and drug abuse, prostitution, political corruption, bankruptcy, and crime. Tourism development can also cause the disappearance of local tradition, materialistic orientation, gambling addiction, and decrease in children's motivation to study. Local people's perception of the environmental impacts of tourism development is generally negative. Perceived adverse environmental factors include noise level, water or air pollution, littering, traffic congestion, environmental destruction, and overcrowding. Economic benefits and city development are the main gains, and various social, cultural, and environmental effects are the losses. Most studies indicate residents' overall support for tourism development can be enhanced as the extent of individual economic reliance on tourism growth directly affects household income (Abujamous et al., 2018 ) reported the contribution of the tourism industry to the economy of Jordan. Kontis et al. (2020) indicated the importance of residents' community participation in planning. Older people tended not to approve tourism development compared with the young generations. A more recent research by Alrwajfah et al., 2019 in Jordan confirmed that residents' optimistic perception of the economic influence of tourism is also validated. The positive economic effect is seen as the primary explanation for the growth of tourism in any region, it is argued. A large body of research has investigated the effect of tourism on the impact of tourism as well as residents' attitude. Because it is hard to separate economic effects from social causes, social influences are considered objectively the most challenging phenomenon for researchers to measure (Anderson, 1981).

Many scholars have used the economic 'gain' concept to objectively measure and analyze social effect events (Marlina et al., 2021; Morar et al., 2020; Setokoe, 2020; Wardana et al., 2020). Since then, the term 'social cost' has been a prevailing tool for describing the severity and meaning of social impacts. However, this method, which relies on the economic effects of evaluating and addressing social costs, has contributed to a variety of controversial debates in the social sciences on what social costs are and what social costs can be described (Mohale et al., 2020; Nzimande and Bob, 2020). The literature review shows that some observational tourism analysis has looked at the impact of the industry on local economic growth, but such a study shows that some observational tourism research has had an impact on local economic growth. Attitude is a psychological characteristic that is expressed in the appraisal of a particular individual with some degrees of gain or loss (Jawabreh, 2019; Eagly and Chiaken, 1993).

Thus, awareness of the mentalities of local communities is critical because recognizing the attitudes of local communities enables tourism stakeholders to introduce an appropriate response mechanism to the negative impacts that arise from local communities (Sammawe,1999; Shannaq, 1996; Show, 1992; Ruby, 1984). Due to tourism activities, both the host and the tourist prosper similarly economically, so developing countries are centered on economic growth by tourism. But, with this significant economic change, both positive and negative results are certain. The notion of tourism is represented in a different way by interested tourism researchers Kolenate, 1991; Nash, 1979). In brief, the literature review illustrates the need for methodological creativity to explain the effect of tourism on the economic development of the community and cruise tourism in particular. Multi-method analyzes focused on the local public could add transparency and detail to this literature instead of macro-level findings and indicators based on the capital asset approach of Escart, 1994.

In the region of destination, the host group is the resident population. The relationship between tourism, tourists and the host culture has been the focus of debate in development planning circles. The vital role of participation and ownership of society at all levels of tourism growth is emphasized. Tourist sector hosts are the people with whom visitors come into touch when visiting the area. Tourism is an important socio-economic practice in today's country. Tourism is now recognized as an industry with a number of social and economic benefits. It promotes national cohesion and economic understanding, contributes to infrastructure improvements, offers employment growth and raises foreign exchange earnings (Kelfaoui et al., 2021; Adhika and Putra, 2020; Hadian et al., 2021; Joseph et al., 2020). Tourism is as variable as any other related socioeconomic function. Because it is arduous to separate economic impacts from social influences, social impacts are regarded as the most difficult phenomenon for researchers to measure scientifically (Goliath-Ludic and Yekela, 2020). Many studies have utilized the economic concept of "cost" to objectively measure and analyze social impact phenomena; thus the term "social cost" has become the dominant medium to identify the strength and dimension of social impacts. However, this approach, which is based on the perspective of economic impacts to analyze and discuss social cost, has triggered many controversial debates of "what social cost is" and "what the definition of social cost should be" in social science. Many scholars conclude that attitudes represent the tendency or structure of feelings, knowledge and behaviors of persons (acting components) as a definition. Studying attitudes therefore allows to understand the actions of individuals, to predict the responses of individuals in the future, and to provide us with the opportunity 
to track and guide conduct across the planning and training processes (Lord, 1997; Leea and Chang, 2008; Lepp, 2006; Mansfield and Jonas, 2006; Pan and Li, 2006; Pizam et al., 1991; Abdel-Rahman, 1992). The main aim of this research is to analyze the connection between the involvement of local populations and the essence of the relationship with sustainable tourism (ethnic, economic and environmental). Clarify the degree of transition in the social patterns and attitudes of the local community in the city of Aqaba, and the results of the analysis are very significant to the planners (Al Hamme, 1988).

\section{METHODOLOGY}

Researchers questioned 1200 people live in Aqaba. Actually retrieved from the circulated questionnaire. From 1st January 2019 to 6th April 2020, delivery and refund took one year when low and high tourist seasons were taken into consideration. Ras Al Khaybar is the only coastal region in Jordan and the most populated place on the shores of the Gulf of Aqabah. Aqaba, the administrative center of the Aqaba Governorate province, is located in southern Jordan. miles, giving it a population density of about the same as Jamaica (144.8 sq mi). Aqāb is an important for the Jordanian economy because of its central location and active trade and tourism sectors. Other countries in the area use the Port of Aq port.

The questionnaire was distributed to the survey participants in order to define, as a predictor of perceptions towards tourism, the most important facets of the socio-cultural and economic effects of tourism in these areas. According to the 5Likert scale, there are 29 questions: 1-strongly unhappily 2-dissatisfied 3-neutral 4-agreed 5-strongly agreed and quantitative research was carried out on the basis of the questionnaires. Aqaba is the only coastal city in Jordan and the biggest and most populated cities in the Gulf of Aqaba. Aqaba is the administrative base of the Government of Aqaba, situated in the southernmost portion of the Jordan. In 2015, the town had a population of 148,398 and 375 square kilometers (144,8 sq mi) of the property. Today, with its booming trade and tourism sectors, Aqaba plays a key role in the development of the Jordanian economy. The Port of Aqaba is also represented by other countries in the region (Jawabreh, 2020). The strategic location of Aqaba on the north-eastern tip of the Red Sea, between the continents of Asia and Africa has made its port significant for thousands of years. The ancient city was called Ayla, which was adopted as Aela in Latin and Ayla in Arabic. Its strategic position and proximity to copper mines made it a regional hub for the processing and exchange of copper in the Chalkolithic period. Under Byzantine control, Ayla became a bishopric and then became a Latin Catholic titular see after the Islamic conquest about AD 650, when it became known as Ayla. The name of Aqaba is a late medieval name (Jawabreh, 2017). The Battle of Aqaba of the Great Arab Revolt, represented in the Lawrence of the Arab Revolution, culminated in the triumph of the Arab powers over the Ottoman defenders. The positioning of Aqaba, next to Wadi Rum and Petra placed it in the Golden Triangle of Jordan, which boosted the location of the city on the world map and made it one of Jordan's major tourist attractions. The region is managed by the Aqaba Special Economic Zone Authority, which has turned Aqaba into a duty-free, low-tax city, attracting several mega-projects such as Ayla Oasis, Saraya Aqaba, Marsa Zayed and the Aqaba Port expansion. In the town, it is expected to turn the region into a major tourist hub.

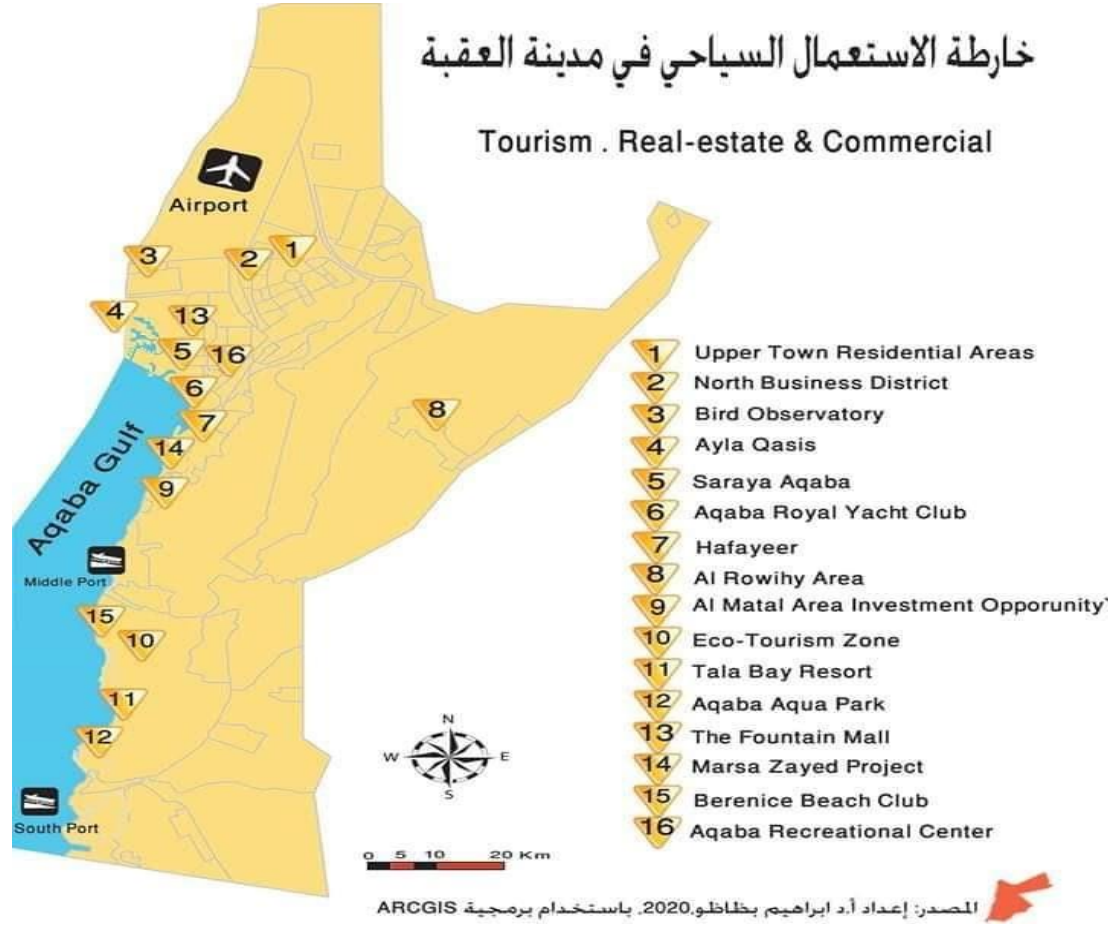

Table 1. Distribution of sample of the study of other variables

\begin{tabular}{|l|l|c|c|}
\hline Variable & \multicolumn{1}{|c|}{ Level } & Frequency & Ratio \\
\hline \multirow{2}{*}{ Gender } & Male & 552 & $65.4 \%$ \\
& Female & 292 & $34.6 \%$ \\
\hline \multirow{2}{*}{ Job } & Public sector & 308 & $40.7 \%$ \\
& Privet sector & 448 & $59.3 \%$ \\
\hline \multirow{5}{*}{ Educatio } & Elementary & & \\
& education & & \\
& Secondary & 64 & $7.6 \%$ \\
& education & 156 & $18.6 \%$ \\
& Diploma & 256 & $30.5 \%$ \\
& University & 332 & $39.5 \%$ \\
& education & 32 & $3.8 \%$ \\
& Post & & \\
& graduation & & \\
\hline \multirow{5}{*}{ Age } & 20 and less & 232 & $27.5 \%$ \\
& $21-30$ & 444 & $52.6 \%$ \\
& $31-40$ & 132 & $15.6 \%$ \\
& 41 and More & 36 & $4.3 \%$ \\
\hline \multirow{5}{*}{ Income } & 150 and less & 228 & $30 \%$ \\
& $151-200$ & 164 & $21.6 \%$ \\
& $201-250$ & 140 & $18.4 \%$ \\
& $251-300$ & 124 & $16.3 \%$ \\
& More than & 104 & $13.7 \%$ \\
\hline
\end{tabular}

Figure 1. Tourism Real-estate and Commercial of Aqaba, Jordan (Bazazo, 2020)

\section{Hypotheses}

1-The interaction of cultural and tourist factors is statistically significant for the local community of Aqaba.

2-Social and tourism factors are statistically closely related to the local community of Aqaba.

3-A statistically relevant correlation exists with the local community of Aqaba between economic and tourism factors. 


\section{ANALYSES}

The characteristics of the survey participants: the demographic specifics of this sample, the results of the analysis of the characteristics of the participants suggest that there were $65.4 \%$ males and $34.6 \%$ females by sex. As far as the profession is concerned, $40.7 \%$ of the sample works in the public sector, while $59.3 \%$ works in the private sector. The effects of the distribution of the sample according to other variables are seen in the Table 1.

Table 2.The level of acceptance on cultural field

\begin{tabular}{|l|l|c|c|c|c|c|}
\hline $\mathbf{N}$ & \multicolumn{1}{|c|}{ Item } & $\begin{array}{c}\text { Strongly } \\
\text { agree }\end{array}$ & Agree & nutrNI & disagree & $\begin{array}{c}\text { stongly } \\
\text { disagree }\end{array}$ \\
\hline 1 & Tourism facilitates the diffusion of & 82 & 114 & 10 & 5 & 1 \\
& cultural heritage. & 38.7 & 53.8 & 4.7 & 2.4 & 0.5 \\
\hline 2 & Tourism applies to and affirms the & 67 & 122 & 19 & 4 & \\
& universal norm of presentation. & 31.6 & 57.5 & 9 & 1.9 & \\
\hline 3 & Tourism represents a high respect for & 82 & 96 & 18 & 11 & 4 \\
& people. & 38.7 & 45.3 & 8.5 & 5.2 & 1.9 \\
\hline 4 & Tourism is helping to learn new & 78 & 98 & 27 & 3 & 3 \\
& international languages. & 36.8 & 46.2 & 12.7 & 1.4 & 1.4 \\
\hline 5 & Tourism opens up new horizons for tourists & 70 & 112 & 17 & 7 & 3 \\
& to experience people's cultures and cultures. & 33 & 52.8 & 8 & 3.3 & 1.4 \\
\hline 6 & Tourism closes the relationship between & 42 & 104 & 35 & 23 & 6 \\
& traditions and practices of various societies. & 19.8 & 49.1 & 16.5 & 10.8 & 2.8 \\
\hline 7 & Tourism closes the relationship between & 48 & 106 & 32 & 16 & 6 \\
& traditions and practices of various societies. & 22.6 & 50 & 15.1 & 7.5 & 2.8 \\
\hline 8 & Tourism has a national uniform for all & 75 & 88 & 29 & 16 & 1 \\
& cultures. & 35.4 & 41.5 & 13.7 & 7.5 & 0.5 \\
\hline 9 & Tourism makes tourists conscious about, & 78 & 110 & 13 & 4 & 1 \\
& and teaches them about their native tongue. & 36.8 & 51.9 & 6.1 & 1.9 & 0.5 \\
\hline 10 & Tourist craft contributes to the & 52 & 105 & 33 & 13 & 5 \\
& preservation of the national heritage. & 24.5 & 49.5 & 15.6 & 6.1 & 2.4 \\
\hline 11 & Tourism seeks to find technological and & 65 & 96 & 20 & 22 & 5 \\
& tourist rehabilitation centers for locals. & 30.7 & 45.3 & 9.4 & 10.4 & 2.4 \\
\hline
\end{tabular}

The study has been split into three areas: economic, social and cultural. The following is a mathematical description of problems in each of these fields. Cultural fields: The results of the Table 2 indicate that most of the respondents either approved or agreed with all of the paragraphs in this portion of the questionnaire. In order to measure the degree of approval in general, the ratio of importance was calculated in the table below. Successful outcomes involve refining cultural practices and reinforcing cultural identity. This cultural sophistication and recognition has been seen to increase the pride of people and to strengthen their cultural identity. The detrimental cultural implications of tourism, involve sacrificing local cultural practices, altering the personal appearance of visitors and weakening local identification. One group of researchers merged the social and cultural impacts of tourism into a similar structure labelled as sociocultural impacts, whilst another group of researchers argued that research into the social and cultural impacts of tourism in isolation provides a much stronger and more holistic perspective. The ratio of priority of the paragraphs in the cultural sector is seen in the Table 3.

In the first position, the results indicate that $82.1 \%$ of respondents comply with the field paragraphs. This may apply to the imitation of such cultural characteristics by groups of tourists. They mimic the traditions, food and clothing of the local community. For e.g., when they reach the city, you can see in Aqaba the eagerness of visitors to wear popular fashion. In the other hand, $15 \%$ disagreed and $11 \%$ neutral. In order to determine the most important paragraphs, the means and standard deviations of the paragraphs in that domain is calculated and then arranged in the order of importance as Table 4.

The findings indicate that the first paragraph on "Tourism can promote and disseminate national heritage" was the most important in this field. The mean and standard deviations of this paragraph are 4.27 and 0.704 consecutively. Paragraph 9 'Tourist craft contributes to the survival of national heritage.' This paragraph has a mean and standard deviation of 4.26 and 0.704 consecutively. The less important paragraph was the sixth: 'Tourism will offer various practices and cultures' Tourist crafts lead to the preservation of national heritage. Together, close.

Table. 4 The means and standard deviation for the importance cultural field

Table 3. The level of the ratio of importance in the field

\begin{tabular}{|c|c|}
\hline $\begin{array}{c}\text { Level } \\
\text { acceptance }\end{array}$ & $\begin{array}{c}\text { The ratio of } \\
\text { importance }\end{array}$ \\
\hline $\begin{array}{c}\text { Strongly } \\
\text { agree }\end{array}$ & 32.1 \\
\hline Agree & 50 \\
\hline Neutral & 11 \\
\hline Disagree & 5.4 \\
\hline $\begin{array}{c}\text { Strongly } \\
\text { disagree }\end{array}$ & 1.5 \\
\hline
\end{tabular}

\begin{tabular}{|c|l|c|c|}
\hline & \multicolumn{1}{|c|}{ Item number } & Mean & $\begin{array}{c}\text { Standard } \\
\text { deviation }\end{array}$ \\
\hline 1 & Tourism facilitates the diffusion of cultural heritage. & .704020 & 4.2783 \\
\hline 2 & Tourism applies to and affirms the universal norm of presentation. & .704840 & 4.2621 \\
\hline 3 & Tourism represents a high respect for people. & .669060 & 4.1887 \\
\hline 4 & Tourism is helping to learn new international languages. & .813940 & 4.1722 \\
\hline 5 & Tourism opens up new horizons for tourists to experience people's cultures and cultures. & .813630 & 4.1435 \\
\hline 6 & Tourism closes the relationship between traditions and practices of various societies. & 914780 & 4.1422 \\
\hline 7 & Tourism closes the relationship between traditions and practices of various societies. & .920970 & 4.0526 \\
\hline 8 & Tourism has a national uniform for all cultures. & 1.02401 & 3.9327 \\
\hline 9 & Tourism makes tourists conscious about, and teaches them about their native tongue. & .931660 & 3.8942 \\
\hline 10 & Tourist craft contributes to the preservation of the national heritage. & .964200 & 3.8365 \\
\hline 11 & Tourism seeks to find technological and tourist rehabilitation centers for locals. & .996470 & 3.7286 \\
\hline
\end{tabular}

(The value of $F$ is statistically significant at the level of significance $\alpha=0,05$ )

Cultural Sector

A T-test, as seen in the Table 5, was performed to confirm this hypothesis:
Table 5. t- test in cultural field

\begin{tabular}{|c|c|c|}
\hline T value & Degree of freedom & The Significant value \\
\hline 29.939 & 211 & .005 \\
\hline
\end{tabular}


According to the T-test $(\mathrm{p}<0.05)$, the results suggest that there is a strong, statistically significant correlation for the Aqaba community between cultural and tourist influences. The mean and standard deviations for this region are typically 4.00 and 0.489 sequences. This indicates that, in addition to the consideration and concern paid to the sharing of local history by these organisation's tourism opens up different horizons for locals to see people's actions and to draw a stunning picture of the region. According to this analysis, the outcomes of the growth of tourism are varied, including improved community life, a positive environment, a positive cultural effect, economic benefits, tourism preparation and a better family life (Atsiz et al., 2020; Doe et al., 2021; Faraji et al., 2020). Generally, the local population of Aqaba viewed the beneficial effect of the growth of tourism in the city of Aqaba. Similarly, residents of Aqaba city that they perceived high quality of life, such as public protection, leisure time, family harmony, group building, the environment of society, health status, economic margins, and living costs. Interestingly, the enhancement of public protection by the growth of tourism contributes to improved community life, a positive atmosphere and a better family life, as community security is directly connected to the perception of happiness among community people. In Aqaba, more leisure time is correlated with more favorable cultural effects, economic benefits and improved family life, as residents appreciate cultural opportunities or economic activities and spend their leisure time with their families.

\section{The social field:}

The results in the Table 6 indicate that most of the respondents either strongly agreed with or agreed with all paragraphs in this field. In general, the value ratio was determined in the table below in order to know the degree of acceptance. In the social sector, the value ratio of the paragraphs is represented in this table:

Table 6. The level of acceptance on social field

\begin{tabular}{|c|c|c|c|c|c|c|}
\hline No & Item & $\begin{array}{c}\text { Strongly } \\
\text { Agree }\end{array}$ & Agree & Neutral & Disagree & \begin{tabular}{|l} 
Strongly \\
Disagree
\end{tabular} \\
\hline 12 & $\begin{array}{l}\text { For tourists, the purpose of tourism is to boost } \\
\text { environmental consciousness. }\end{array}$ & $\begin{array}{c}67 \\
31.9\end{array}$ & $\begin{array}{c}113 \\
53.8\end{array}$ & $\begin{array}{l}18 \\
8.6\end{array}$ & $\begin{array}{l}10 \\
4.8\end{array}$ & $\begin{array}{l}2 \\
1\end{array}$ \\
\hline 13 & $\begin{array}{l}\text { Tourism promotes the expansion of excavation } \\
\text { and study into national antiques. }\end{array}$ & $\begin{array}{c}65 \\
30.7\end{array}$ & $\begin{array}{r}108 \\
50.9\end{array}$ & $\begin{array}{c}22 \\
10.4\end{array}$ & $\begin{array}{l}13 \\
6.1\end{array}$ & \\
\hline 14 & $\begin{array}{l}\text { Tourism aims to characterize the private } \\
\text { standard of the person. }\end{array}$ & $\begin{array}{c}41 \\
19.3\end{array}$ & $\begin{array}{l}114 \\
53.8\end{array}$ & $\begin{array}{c}37 \\
17.5\end{array}$ & $\begin{array}{l}13 \\
6.1\end{array}$ & $\begin{array}{c}4 \\
1.9\end{array}$ \\
\hline 15 & $\begin{array}{l}\text { Tourism's practices and behaviors are } \\
\text { diminishing as a product of human conformity. }\end{array}$ & $\begin{array}{c}40 \\
18.9\end{array}$ & $\begin{array}{c}81 \\
38.2\end{array}$ & $\begin{array}{c}37 \\
17.5\end{array}$ & $\begin{array}{l}34 \\
16\end{array}$ & $\begin{array}{r}12 \\
5.7\end{array}$ \\
\hline 16 & $\begin{array}{l}\text { Tourism leads to the spread of patterns and } \\
\text { ethical practices }\end{array}$ & $\begin{array}{c}50 \\
23.6\end{array}$ & $\begin{array}{c}71 \\
33.5\end{array}$ & $\begin{array}{c}36 \\
17.0\end{array}$ & $\begin{array}{c}30 \\
14.2\end{array}$ & $\begin{array}{c}19 \\
9\end{array}$ \\
\hline 17 & $\begin{array}{l}\text { Tourism weakens the bonds of friendship } \\
\text { between the party's leaders. }\end{array}$ & $\begin{array}{c}38 \\
17.9 \\
\end{array}$ & $\begin{array}{c}85 \\
40.1 \\
\end{array}$ & $\begin{array}{c}45 \\
21.2\end{array}$ & $\begin{array}{c}30 \\
14.2 \\
\end{array}$ & $\begin{array}{c}8 \\
3.8 \\
\end{array}$ \\
\hline 18 & $\begin{array}{l}\text { Tourism promotes people's religious } \\
\text { inclination. }\end{array}$ & $\begin{array}{c}37 \\
17.5\end{array}$ & $\begin{array}{c}44 \\
20.8\end{array}$ & $\begin{array}{c}49 \\
23.1\end{array}$ & $\begin{array}{c}43 \\
20.3\end{array}$ & $\begin{array}{l}37 \\
7.5\end{array}$ \\
\hline 19 & Tourism is hindering the faith of man. & $\begin{array}{c}42 \\
19.8\end{array}$ & $\begin{array}{c}73 \\
34.4\end{array}$ & $\begin{array}{c}37 \\
17.5\end{array}$ & $\begin{array}{c}33 \\
15.6\end{array}$ & $\begin{array}{c}24 \\
11.3\end{array}$ \\
\hline 20 & $\begin{array}{l}\text { Knowledge of shrines and religious places will } \\
\text { add to the understanding of particular faiths. }\end{array}$ & $\begin{array}{c}26 \\
12.3\end{array}$ & $\begin{array}{c}49 \\
23.1\end{array}$ & $\begin{array}{c}46 \\
21.7\end{array}$ & $\begin{array}{c}58 \\
27.4\end{array}$ & $\begin{array}{c}30 \\
14.3\end{array}$ \\
\hline 21 & $\begin{array}{l}\text { Some social norms, such as gender separation, } \\
\text { are dominated by tourism. }\end{array}$ & $\begin{array}{c}54 \\
25.5 \\
\end{array}$ & $\begin{array}{l}72 \\
34 \\
\end{array}$ & $\begin{array}{c}38 \\
17.9 \\
\end{array}$ & $\begin{array}{c}22 \\
10.4\end{array}$ & $\begin{array}{l}18 \\
8.5\end{array}$ \\
\hline
\end{tabular}

Table 7. The ratio

of relativeimportance in the social field

\begin{tabular}{|c|c|}
\hline $\begin{array}{c}\text { Ratio of } \\
\text { Acceptance }\end{array}$ & $\begin{array}{c}\text { Relative } \\
\text { importance }\end{array}$ \\
\hline $\begin{array}{c}\text { Strongly } \\
\text { agree }\end{array}$ & 22.2 \\
\hline Agree & 39 \\
\hline Neutral & 17.6 \\
\hline Disagree & 13.8 \\
\hline $\begin{array}{c}\text { Strongly } \\
\text { disagree }\end{array}$ & 7.4 \\
\hline
\end{tabular}

Table 8.. The mean and standard deviation of the importance social field

\begin{tabular}{|c|c|c|c|}
\hline Item number & Mean & Standard deviation & \\
\hline For tourists, the purpose of tourism is to boost environmental consciousness. & 4.1095 & .81985 & 1 \\
\hline Tourism promotes the expansion of excavation and study into national antiques. & 4.0817 & .81534 & 2 \\
\hline Tourism aims to characterize the private standard of the person. & 3.8373 & .87834 & 3 \\
\hline Tourism's practices and behaviors are diminishing as a product of human conformity. & 3.5980 & 1.23384 & 4 \\
\hline Tourism leads to the spread of patterns and ethical practices & 3.5583 & 1.07022 & 5 \\
\hline Tourism weakens the bonds of friendship between the party's leaders. & 3.5049 & 1.15540 & 6 \\
\hline Tourism promotes people's religious inclination. & 3.5000 & 1.26008 & 7 \\
\hline Tourism is hindering the faith of man. & 3.3636 & 1.28296 & 8 \\
\hline Knowledge of shrines and religious places will add to the understanding of particular faiths. & 3.0048 & 1.35370 & 9 \\
\hline Some social norms, such as gender separation, are dominated by tourism. & 2.9187 & 1.25885 & 10 \\
\hline
\end{tabular}

The findings Table 7 reveal that 39.0 percent of respondents agree with this domain's paragraph, and 22.2 percent strongly agree. While as there was 13.8 percent opposed, 7.4 percent firmly opposed and 17.6 percent neutral.

And in order to evaluate the most relevant paragraphs, the means and standard deviations of the paragraphs in this domain were measured and then ordered in an order of significance as Table 8.

Second, the results indicate that Topic No.12 'Tourism Encourages Prolonged Exploration and Research of National Monuments' was the most important paragraph in this area, with a mean of 4.10 and a standard deviation of 0.81 . Second, the results indicate that paragraph 20 , 'Getting details on shrines and religious places would lead to raising understanding about particular faiths,' with an average of 2.91 and a standard deviation of 1.25 , was less important.

\section{Social Field}

A t test was conducted as Table 9 to verify this hypothesis. 
Table 9. $\mathrm{t}$ test in social field

\begin{tabular}{|l|l|l|}
\hline T value & Degree of freedom & The significant value \\
\hline
\end{tabular} \begin{tabular}{|l|l|}
\hline 11.642 & 210 \\
\hline
\end{tabular}
The findings show that for the people living in Aqaba, there is a statistically important connection between social and tourism influences. In this area, the general mean was 3.48 and the standard deviation was 0.60 .

\section{The Field of Economy:}

The findings in the Table 10 reveal that most respondents either strongly agree with all the paragraphs in this area or agree with them. In general, in order to know the degree of acceptance, the ratio of value has been determined in the table below. This table illustrates the ratio of the economic relevance of the paragraphs:

Table 10. he level of acceptance on economic field

\begin{tabular}{|c|c|c|c|c|c|c|}
\hline $\mathbf{N}$ & Item & $\begin{array}{c}\text { Strongly } \\
\text { agree }\end{array}$ & Agree & Neutral & sagreedi & $\begin{array}{l}\text { stongly } \\
\text { disagree }\end{array}$ \\
\hline 22 & $\begin{array}{l}\text { Tourism substantially decreases the number of } \\
\text { unemployed persons. }\end{array}$ & $\begin{array}{c}80 \\
37.7\end{array}$ & $\begin{array}{c}96 \\
45.3\end{array}$ & $\begin{array}{c}19 \\
9\end{array}$ & $\begin{array}{l}10 \\
4.7\end{array}$ & $\begin{array}{c}3 \\
1.4\end{array}$ \\
\hline 23 & $\begin{array}{l}\text { Tourism promotes the multiplicity and diversity } \\
\text { of work openings. }\end{array}$ & $\begin{array}{c}103 \\
48.6\end{array}$ & $\begin{array}{c}84 \\
39.6\end{array}$ & $\begin{array}{l}12 \\
5.7\end{array}$ & $\begin{array}{l}2 \\
9\end{array}$ & $\begin{array}{c}4 \\
1.9\end{array}$ \\
\hline 24 & Tourism is contributing to raise national wages. & $\begin{array}{c}98 \\
46.2\end{array}$ & $\begin{array}{c}93 \\
43.9\end{array}$ & $\begin{array}{c}8 \\
3.8\end{array}$ & $\begin{array}{c}6 \\
2.8\end{array}$ & $\begin{array}{c}3 \\
1.4\end{array}$ \\
\hline 25 & $\begin{array}{l}\text { Tourism plays an important part in improving the } \\
\text { quality of raw materials (food and clothing). }\end{array}$ & $\begin{array}{c}76 \\
35.8\end{array}$ & $\begin{array}{l}105 \\
49.5\end{array}$ & $\begin{array}{l}18 \\
8.5\end{array}$ & $\begin{array}{c}8 \\
3.8\end{array}$ & $\begin{array}{l}2 \\
9\end{array}$ \\
\hline 26 & $\begin{array}{l}\text { Tourism is opening up modern investment } \\
\text { projects. }\end{array}$ & $\begin{array}{c}55 \\
25.9\end{array}$ & $\begin{array}{c}97 \\
45.8\end{array}$ & $\begin{array}{c}40 \\
18.9\end{array}$ & $\begin{array}{l}11 \\
5.2\end{array}$ & $\begin{array}{c}4 \\
1.9\end{array}$ \\
\hline 27 & $\begin{array}{l}\text { Tourism is contributing to the protection of the } \\
\text { national capital. }\end{array}$ & $\begin{array}{c}50 \\
23.6\end{array}$ & $\begin{array}{r}117 \\
55.2\end{array}$ & $\begin{array}{c}29 \\
13.7\end{array}$ & $\begin{array}{c}8 \\
3.8 \\
\end{array}$ & $\begin{array}{c}5 \\
2.4 \\
\end{array}$ \\
\hline 28 & Tourism is drawing international towns. & $\begin{array}{c}93 \\
43.9\end{array}$ & $\begin{array}{c}94 \\
44.3\end{array}$ & $\begin{array}{l}12 \\
5.7\end{array}$ & $\begin{array}{c}7 \\
3.3\end{array}$ & $\begin{array}{l}2 \\
9\end{array}$ \\
\hline 29 & Multinational companies are attracted to tourism. & $\begin{array}{c}91 \\
42.9 \\
\end{array}$ & $\begin{array}{l}101 \\
47.6\end{array}$ & $\begin{array}{c}10 \\
47.6\end{array}$ & $\begin{array}{c}7 \\
3.3 \\
\end{array}$ & \\
\hline
\end{tabular}

Table 11. The level of relative importance in the economic field

\begin{tabular}{|c|c|}
\hline $\begin{array}{c}\text { Level } \\
\text { acceptance }\end{array}$ & $\begin{array}{c}\text { Relative } \\
\text { importance }\end{array}$ \\
\hline $\begin{array}{c}\text { Strongly } \\
\text { agree }\end{array}$ & 38.8 \\
\hline Agree & 47.3 \\
\hline Neutral & 8.9 \\
\hline Disagree & 3.5 \\
\hline $\begin{array}{c}\text { Strongly } \\
\text { disagree }\end{array}$ & 1.5 \\
\hline
\end{tabular}

With respect to the Table 11 , the results indicate that $47.3 \%$ of respondents agree with paragraphs in this area and 38.8 per cent strongly agree, although 3.5 per cent strongly disagree with $1.5 \%$ and $8.9 \%$ neutral. The most relevant paragraphs, means and standard deviations of the paragraphs of this domain were calculated with a view to disclosing them, and were arranged in an order with regard to the sense as Table 12. The most significant paragraph in this area, as shown in the Table 13, is question No. 23, 'Tourism contributes to a rise in national income,' with an average of 4.36 and a standard deviation of 0.80 . No. 26, 'Tourism opens fresh insights for investment projects,' is, the less significant side, with an average of 2.91 and a standard deviation of 1.25. Hypothesis of the economic field. In order to verify this hypothesis T test was used the following:

Table .12. The mean and standard deviation for the importance economical field

\begin{tabular}{|c|c|c|c|c|c|c|}
\hline Item Number & Mean & \begin{tabular}{l|} 
Standard \\
deviation
\end{tabular} & & \multirow{3}{*}{\multicolumn{3}{|c|}{$\begin{array}{l}\text { Table } 13 . \mathrm{t} \text { test } \\
\text { in cultural field }\end{array}$}} \\
\hline Tourism substantially decreases the number of unemployed persons. & 4.3659 & & 1 & & & \\
\hline Tourism promotes the multiplicity and diversity of work openings. & 4.3317 & & 2 & & & \\
\hline Tourism is contributing to raise national wages. & 4.3206 & & 3 & \multirow{2}{*}{$\begin{array}{c}\mathrm{T} \\
\text { value }\end{array}$} & \multirow{2}{*}{$\begin{array}{c}\text { Degree } \\
\text { of } \\
\text { freedom }\end{array}$} & \multirow{2}{*}{$\begin{array}{l}\text { Significant } \\
\text { value }\end{array}$} \\
\hline Tourism plays an important part in improving the quality of raw materials (food and clothing). & 4.2933 & & 4 & & & \\
\hline Tourism is opening up modern investment projects. & 4.1722 & & 5 & \multirow[t]{4}{*}{\begin{tabular}{|l|}
26.954 \\
\end{tabular}} & \multirow{4}{*}{209} & \multirow[t]{4}{*}{0.00} \\
\hline Tourism is contributing to the protection of the national capital. & 4.1538 & & 6 & & & \\
\hline Tourism is drawing international towns. & 3.9522 & & 7 & & & \\
\hline Multinational companies are attracted to tourism. & 3.9082 & & 8 & & & \\
\hline
\end{tabular}

The results suggest that the Aqaba community has a statistically relevant association between economic and tourism variables. In general, the mean is 4.14 and the standard deviation is 0.6155 .

\section{CONCLUSION}

The present study indicates three conclusions as follows: as is apparent from the results of the analysis, the economic sector falls to the first degree with an acceptable level of $86.1 \%$ of the survey group. The second degree is the cultural sector with an approval ratio of $82 \%$ and, ultimately, the social field with an approval ratio of $61.1 \%$. This demonstrates that the local population of Aqaba is directly aware of the monetary benefits of tourism activities in its region. According to the survey, about one third of the sample in the social sector is either opposed or neutral. In contrast, "Tourism concerns ruins through the process of exploration" is the most important paragraph in this area. Researchers find that about $7 \%$ of the study's allocated participants indicated that the negative change in tourism activities will bring about the local culture of community members in Aqaba. Unlike other industries, tourism includes travelers visiting the places where citizens operate, thus the involvement of tourists increases the likelihood of friction between tourists and residents. It is also important that citizens' opinions on the effects of tourism are carefully observed and documented. This will help to settle on an optimal preparation for the growth of tourism while at the same time attenuating the detrimental impact of this production on the residential community. 
The connection between the attitude of tourism (culture) and the influence of tourism in Aqaba is statistically relevant. If tourism promotes the spread of national heritage, represents a good reputation for people, allows to acquire modern international languages, broadens new horizons for citizens recognize the customs of cultures and rituals, and closes links between the customs and traditions of different communities. Presents national uniformity among all cultures, makes the person aware of and recognizes his/her native language, contributes to the preservation of national heritage, contributes to the exploration of citizens' technical and visitor centers and promotes the return of heritage. In contrast, the results show that citizens are oblivious to the cultural impact of tourism. Similar results are reported in Dawlish, UK, Tosun, 2002, Williams and Lawson, 2001; Wilson,1997, who noticed that people may not attribute much importance to the cultural effects of tourism.

This could be attributed to the lack of awareness on the part of the community regarding the negative social and cultural costs expected by the growth of tourism to gain economic benefits. The connection between tourism (social) attitudes and the influence of tourism in Aqaba is statistically significant. Thus, in the sense of quality of life, it can be concluded that there is a clear divide between educated and uneducated citizens, with educated people getting a more optimistic view of the impact of tourism. Finally, the cultural influence indicates that the disparity in interpretation is motivated. The findings are reflective for individuals, where it helps to increase environmental consciousness, encourages increased discovery and analysis of national antiques, helps to understand the individual's personal features, decreases the individual's adherence to norms and rituals, helps disperse habits and ethical values, weakens social relations between community members, according to Robin Study (Robin and Haywantee, 2011; Lindsay and Kerstetter, 2014). This could be attributed to the sensitivity of locals to the detrimental social and cultural costs of the economic gains predicted from the rise of tourism. In addition, studies show that locals adversely align tourist development with quality of life. This ensures that people link variables such as elevated traffic and crowds in the area, unhygienic public spaces and facilities, environmental pollution and habitat degradation.

Kannapa, 2011, noted the position of local leader and collaboration between tourism stakeholders in planning and execution that led the community to follow the growth of local tourism, Mansfield and Jonas noted that the effect on citizens living farther away from the tourist areas was more negative (Mansfield and Ginosa,1994). However Sheldon and Var, 1984 said that residents in areas with higher tourist density were more optimistic about the rise in tourism (Marphy,1982; Kannapa, 2011; Timothy et al., 2013). Hinders' theological efficacy, which contributes to a greater comprehension of the religion of an individual, reinforces societal practices such as gender division, and confirms respect for women in public places. Furthermore, the findings suggest that locals have a good feeling about the economic effects of tourism growth (Rafi and Herdiansyah, 2020). The connection between tourism (economic) attitudes and the influence of tourism in Aqaba is statistically significant. Where the degree of unemployment is reduced, the multiplicity and diversity of work prospects are encouraged, contributing to an improvement in national income, the effect of tourism studies has been confined to economic studies and benefits for the area. It is fair to believe that the positive economic effects of tourism have led to the development of a positive image of tourism among local residents. In the other side, tourism development is criticized for its detrimental effects, such as increasing living costs, inflation in land and house prices, insecure and low-paid employment. However, these positive economic impacts have been seen to promote the growth of tourism in the region. Concern has recently been posed about the existence of harmful consequences (Pizam, 1978) assess their comprehension about how tourism impacts different realms, they were interviewed. By combining the scores of each respondent, the Attitude-Index was created (Abed al Jabber, 1996). Comparisons have been made between the perceptions of the respondent towards tourism and their dependency on tourism for their livelihoods. However, studies suggest that locals have a strong sense of the economic influence of the growth of tourism. For example, a variety of studies show similar findings.

As well as employment, schooling has remained a clear predictor of citizens' awareness and perceptions towards the effects of tourism. People of higher education standards are considered to have a more optimistic view of the impact of tourism. Several research has shown, empirically, both in industrialized and developing countries, that citizens with higher education have a more favorable view of the effects of tourism, such as Among resident groups of differing levels of education, and different levels of perception are also expected. Those with a higher level of education will see the outcomes of tourism more positive than those with a lower level of education. Lindsay draws on the knowledge of locals who have grown used to the rise of surf tourism facilities and services. The trend of tourism firms and regional tourism industries is that wages, incomes and tax collections quantify their value to the host group, even as any member of that community is impacted on a regular basis by a wide variety of impacts (Bob et al., 2019; Timothyet al., 2013; Lindsay and Kerstetter, 2014; Hair et al., 2012).

It plays an important role in improving the quality of raw materials (food and clothing), opening up new possibilities for investment projects, helping to maintain domestic resources, attracting external capital, attracting international corporations, helping to enter the country in foreign currency, leading to the growth of new trade routes, fostering the capacity of the air fleet and the qua. In addition, Amyan et al., 2011, find that tourism development has a negative impact on the natural environment and is closely related to an increase in air and water emissions (Sima o and Mo^sso, 2013), who noticed in Sal Island that locals believed that tourism development had detrimental effects on the host community, have published similar results. It therefore indicates that, if the demands of the people are not adequately met, the future prospects for growth in tourism in Kashmir could face significant challenges. The association between the attitudes of tourism (political) and the results of tourism in Aqaba is statistically significant. Where it promotes the development of international relations with other countries, strengthens the country's unity, contributes to democratic prosperity, enhances social cohesion, stimulates equality in the country, contributes to raising citizens' political understanding, and enhances national party government programs.

\section{REFERENCES}

Abed al Jabber, T. (1996). The importance of tourism in the Jordanian economy. Environmental Foundation in Jordan.

Abdel-Rahman, A. (1992). Trends of students studying in the Faculty of teacher education towards high teaching profession. Moata Research and Studies, 27(2). 
Abujamous, I., Jawabreh, O., Jahmani, A., Alsarayreh, M., \& Harazneh, A. (2018). Developing tourism through sports events to assisting the rejuvenation of the strategic position of the Aqaba Special Economic Zone Authority (ASEZA). African Journal of Hospitality, Tourism and Leisure, 8 (4).

Adhika, I.M., \& Putra, I.D.G.A.D. (2020). Reinvigorating cultural landscapes for planning cultural tourism in Bali. GeoJournal of Tourism and Geosites, 33(4spl), 1462-1469. https://doi.org/10.30892/gtg.334spl03-594

Anderson, M. (1981). Work and leisure. In Routledge Kagan Paul, London

Alfandi, A.M. (2020). Is Jordan safe to visit? the impact of perceived risk perceptions on the tourist behavioural intentions. GeoJournal of Tourism and Geosites, 33(4spl), 1545-1550. https://doi.org/10.30892/gtg.334spl15-606

Al Hamme, A. (1988). Tourism and tourism development in the Arab Republic of Egypt. Conference tourism in Egypt, Mansoura University, Faculty of Commerce, 1-3 July,1988, Egypt.

Al-Nasser, M. (1999). A study on the dimensions and political motives for tourism and reality and aspiration, a critical study analysis Humanities and Social Sciences, 26(5), 220-230.

Alrwajfah, M., García, F., Macias, R. (2019). Residents' Perceptions and Satisfaction toward Tourism Development: A Case Study of Petra Region, Jordan. Sustainability, 11(1907), 1-20.

Alroadie, Ziad, (2007). The Golden Triangle "Petra, Aqaba and Aqaba". Municipality of Amman, Jordan.

Al Salal, Aida (2003). Archaeology and tourist sites. the first edition, Al zarka, Jordan.

Asharu, M. (1983). The impact of interest from parents to collect their children and their attitudes towards school and study materials at the third preparatory grade students in Jordan. Unpublished Master Thesis, Yarmouk University, Irbid - Jordan.

Amyan, M., Jawabreh, O., Alsarayreh, M., \& Malkawi, N. (2011). Mutual Impact between Tourism and the Host Community (A Case Study of Wadi Rum. European Journal of Social Sciences, 19(1).

Atsız, O., Leoni, V., \& Akova, O. (2020). Determinants of tourists' length of stay in cultural destination: one-night vs longer stays. Journal of Hospitality and Tourism Insights. https://ezlibrary.ju.edu.jo:2057/10.1108/JHTI-07-2020-0126

Bazazo, I. (2020). Geography of tourism in Jordan. Yazouri Group for Publication and Distribution, Jordan.

Bob, U., Swart, K., Gounden, R., Gumede, A., \& Nkambule, S. (2019). Socioeconomic impacts of the festivals and events sub-category of the mzansi golden economy programme in South Africa. GeoJournal of Tourism and Geosites, 27(4), 1236-1250. https://doi.org/10.30892/gtg.27410-429

ÇavuĢoğlu, S., Demirağ, B., Jusuf, E., \& Gunardi, A. (2020). The effect of attitudes toward green behaviors on green image, green customer satisfaction and green customer loyalty. GeoJournal of Tourism and Geosites, 33(4spl), 1513-1519. https://doi.org/10.30892/gtg.334spl10-601

Chigora, F., Mutambabra, E., Ndlovu, J., Muzurura, J., \& Zvavahera, P. (2020). Towards Establishing Zimbabwe Tourism Destination Brand Equity Variables through Sustainable Community Involvement. African Journal of Hospitality, Tourism and Leisure, 9(5), $1094-1110$. https://doi.org/10.46222/ajhtl.19770720-71

Doe, F., Preko, A., Akroful, H., \& Okai-Anderson, E.K. (2021). Festival tourism and socioeconomic development: case of Kwahu traditional areas of Ghana. International Hospitality Review. https://ezlibrary.ju.edu.jo:2057/10.1108/IHR-09-2020-0060

Eagly, A., \& Chiaken, S. (1993). The psychology of Attitudes. Harcourt Brace Jovanovich College Publishers, Fort Worth, Texas.

Escart, T. (1994). Aqaba in southern Jordan. Harrow School, London.

Faraji, A., Khodadadi, M., Nematpour, M., Abidizadegan, S., \& Yazdani, H.R. (2020). Investigating the positive role of urban tourism in creating sustainable revenue opportunities in the municipalities of large-scale cities: the case of Iran. International Journal of Tourism Cities, 7(1), 177-199. https://ezlibrary.ju.edu.jo:2057/10.1108/IJTC-04-2020-0076

Garidzira, R., \& Pasara, M.T. (2020). An analysis of the contribution of tourism on economic growth in South African provinces: a panel analysis. GeoJournal of Tourism and Geosites, 29(2), 554-564. https://doi.org/10.30892/gtg.29214-489

Goliath-Ludic, K., \& Yekela, S. (2020). Resident's perception of the environmental impact of tourism: a case study of the Bawa community in butterworth, South Africa. GeoJournal of Tourism and Geosites, 33(4spl), 1527-1531. https://doi.org/10.30892/gtg.334spl12-603

Gorochnaya, V., Mikhaylov, A., Plotnikova, A., \& Mikhaylova, A. (2021). The interdependence between tourism and innovation activity in the western borderlands of Russia. GeoJournal of Tourism and Geosites, 34(1), 147-154. https://doi.org/10.30892/gtg.34119-630

Gozgor, G., \& Ongan, S. (2017). Economic policy uncertainty and tourism demand: empirical evidence from the USA. International Journal of Tourism Research, 19, 99-106. https://doi.org/10.1002/jtr.2089

Hadian, M.S.D., Suganda, B.R., Khadijah, U.L.S., \& Anwar, R.K. (2021). River development as a sustainable geo-tourism with a participatory stakeholder approach. GeoJournal of Tourism and Geosites, 34(1), 155-163. https://doi.org/10.30892/gtg.34120-631

Hair, F., Sarstedt, M., Ringle, C.M., \& Mena, A. (2012). An assessment of the use of partial least squares structural equation modeling in marketing research. Journal of the Academy of Marketing Science, 40(3), 414-433. https://doi.org/10.1007/s11747-011-0261-6

Harilal, V., \& Tichaawa, T.M. (2020). Community Perceptions of the Economic Impacts of Ecotourism in Cameroon. African Journal of Hospitality. Tourism and Leisure, 9(6):959-978. https://doi.org/10.46222/ajhtl.19770720-62

Hermann, U.P., Tshipala, N.N., \& Dlamini, N.N. (2020). An Exploratory Analysis of Visitor Spending at a Cultural Event in Eswatini. African Journal of Hospitality. Tourism and Leisure, 9(5), 1193- 1204. https://doi.org/10.46222/ajhtl.19770720-77

Hwang, J., \& Lee, S. (2015). The effect of the rural tourism policy on non-farm income in South Korea. Tourism Management, 46, 501-513. https://doi.org/10.1016/j.tourman.2014.07.018

Jawabreh, O. (2020). Innovation management in hotels industry in Aqaba Special Economic Zone Authority; hotel classification and administration as a moderator. GeoJournal of Tourism and Geosites, 32(4), 1362- 1369. https://doi.org/10.30892/gtg.32425-581

Jawabreh, O. (2019).The Management of Tourism Crises in Jordan: Amman Hotels' Bombing Case Study. African Journal of Hospitality, Tourism and Leisure, 8(1).

Jawabreh, O. (2017). Distinction of Jordan as a destination for religious tourism. Journal of Environmental Management and Tourism, 6(22), 1171-1182. https://doi.org/10.14505/jemt.v8.6(22).03

Joseph, E.K., Kallarakal, T.K., Varghese, B., \& Antony, JK. (2020). Sustainable tourism development in the Backwaters of South Kerala, India: the local government perspective. GeoJournal of Tourism and Geosites, 33(4spl), 1532-1537. https://doi.org/10.30892/gtg.334spl13-604

Kannapa, P. (2011). Participatory management process in local tourism development: A case study on fisherman village on Samui Is land, Thailand. Asia Pacific Journal of Tourism Research, 16, 57-73. https://doi.org/10.1080/10941665.2011.539391

Kelfaoui, A., Rezzaz, A.M., \& Kherrour, L. (2021). Revitalization of mountain rural tourism as a tool for sustainable local development in Kabylie (Algeria). The case of Yakouren municipality. GeoJournal of Tourism and Geosites, 34(1), 112-125. https://doi.org/10.30892/gtg.34115-626

Kolenate, K.S. (1991). Geography of tourism and leisure. Translator Nasim Barham. Publications, University of Jordan, Deanship of Scientific Research, Amman, Jordan. 
Kontis, A.P., Doumi, M., Kyriakaki, A., \& Mouratidis, K. (2020). Residents’ Perceptions of Tourism Impact on Local Economic Development During the Economic Crisis: The Case of Kavala. In: Kavoura A., Kefallonitis E., Theodoridis, P. (eds) Strategic Innovative Marketing and Tourism. Springer Proceedings in Business and Economics. Springer, Cham. https://doi.org/10.1007/978-3-030-36126-6_68

Leea, C., \& Changb, C. (2008). Tourism development and economic growth: A closer look at panels. Tourism Management, $29(1), 180-192$. https://doi.org/10.1016/j.tourman.2007.02.013

Lepp, A. (2006). Residents' attitudes towards tourism in Bigodi village, Uganda. Tourism Management, 28(3), 876-885. https://doi.org/10.1016/j.tourman.2006.03.004

Lekgau, R.J., \& Tichaawa, T.M. (2020). Community Perceptions on the Socio-economic Impacts of Wildlife Tourism from the Kgalagadi Transfrontier Park in Botswana: The Case of Tsabong. African Journal of Hospitality. Tourism and Leisure, 9(6), 1044-1059. https://doi.org/10.46222/aihtl.19770720-67

Li, G., Song, H., \& Witt, S.F. (2005). Recent developments in econometric modeling and forecasting. Journal of Travel Research, 44(1), 8299. https://doi.org/10.1177/0047287505276594

Lindsay, E.U., Kerstetter, D. (2014). Residents' perceptions of quality of life in a surf tourism destination: A case study of Las Salinas, Nicaragua. Progress in Development Studies, 14(4), 321-333. https://doi.org/10.1177/1464993414521525

Lord, C. (1997). Social Psychology. Harcourt Brace College Publishers, Fort Worth, Texas.

Maaiah, B.S., \& Wouhoush, O.N. (2020). Jordanian culture and traditions as a driving force for attracting dutch tourists. GeoJournal of Tourism and Geosites, 33(4spl), 1450-1455. https://doi.org/10.30892/gtg.334spl01-592

Mansfield, Y., \& Jonas, A. (2006). Evaluating the socio-cultural carrying capacity of rural tourism communities: A "value stretch" approach. Journal of Economic and Social Geography, 97(5), 583-601. https://doi.org/10.1111/j.1467-9663.2006.00365.x

Mansfield, Y., \& Ginosar, U. (1994). Repertory grid techniques in tourist. Environment and Planning, 26 (6), 95-111.

Marphy, P. (1985). Tourism: a community approach. University press Cambridge, UK.

Marlina, S., Astina, I.K., \& Susilo, S. (2021). Social-economic adaptation strategies of bajo mola fishers in Wakatobi national park. GeoJournal of Tourism and Geosites, 34(1), 14-19. https://doi.org/10.30892/gtg.34102-613

Mohale D.M., McKay, T., \& Van der Merwe, C.D. (2020). The Nature of Cultural and Heritage Tourism in Greater Polokwane, Limpopo, South Africa. African Journal of Hospitality, Tourism and Leisure, 9(6), 930-943. https://doi.org/10.46222/ajhtl.19770720-60

Morar, C., Grama, V., Stupariu, I.M., Nagy, G., Boros, L., Tiba, Al., Gozner, M., \& Szabo-Alexi, S. (2020). Local perspectives over cultural tourism to heritage sites. the case study of oradea fortress (Romania). GeoJournal of Tourism and Geosites, 33(4spl), 1470-1479. https://doi.org/10.30892/gtg.334spl04-595

Nash, D. (1981). Tourism as an anthropology subject. Current Anthropology. University of Chicago, USA.

Nzimande, S.R., \& Bob, U. (2020). Stakeholder perceptions and understanding of EcoCultural Resorts: The proposed Eco-Culture Resort in the Chelmsford Nature Reserve, KwaZulu-Natal, South Africa. African Journal of Hospitality, Tourism and Leisure, 9(6):1012-1026. https://doi.org/10.46222/ajhtl.19770720-65

Owens, C,.(992). Data gathering for community oriented tourism planning. Leisure Studies, 11(1), 65-79.

Pan, Q., \& Li, X. (2006). A study on the impact of tourism on the traditional custom culture of destination: A case study of Xi'an. Areal Research and Development, 25(1), 83-87.

Pizam, A., Milman A., \& Jafari, J. (1991). Influence of tourism on attitudes: U.S. students visiting USSR. Tourism Management, 12(1), 4754. https://doi.org/10.1016/0261-5177(91)90028-R

Peng, C., \& Yuan, P. (2019). Influence of environmental regulations on China's tourism competitiveness: Empirical evidence based on provincial panel data. Nankai Business Review International, 10(3), 429-446. https://ezlibrary.ju.edu.jo:2057/10.1108/NBRI-12-2017-0073

Robin ,N, Haywantee ,R..(2011). Residents' Satisfaction With Community Attributes and Support for Tourism. Journal of Hospitality \& Tourism Research, 35(2), 171-190. https://doi.org/10.1177/1096348010384600

Rafi, F., \& Herdiansyah, H. (2020). The impact of koja cliff development on social-cultural and economic: case of community-based tourism, Banten, Indonesia. GeoJournal of Tourism and Geosites, 28(1), 164-174. https://doi.org/10.30892/gtg.28113-460

Ruby, N. (1984). Tourism Economics. Cultural Foundation. University Publishing, Alexandria, Egypt.

Sammawe, H. (1999). Tourism and rambles in Balqa Governorate characteristics and trends studies. University of Jordan, 17.

Setokoe, T.J. (2020). Community-based tourism: a panacea for community development in Nqileni Village, Eastern Cape, South Africa. GeoJournal of Tourism and Geosites, 34(1), 28-32. https://doi.org/10.30892/gtg.34104-615

Shannaq. M. (1996). The social dimension of tourism in the northern Jordan. Irbid Private University, Irbid.

Sheldon, P.J., \& Var, T. (1984). Residents Attitudes to Tourism in North Wales. Tourism Management, 5, 40-47. https://doi.org/ $10.1177 / 004728759002800301$

Show, G. (1992). Culture and tourism. World Futures, UK.

Simão, J., \& Mo^sso, A. (2013). Residents' perceptions towards tourism development: The case of Sal island. International Journal of Development Issues, 12(2), 140-157. https://doi.org/10.1108/IJDI-12-2012-0076

Song, H., Dwyer, L., Li, G., \& Cao, Z. (2012). Tourism economics research: a review and assessment. Annals of Tourism Research, 39(3), 1653-1682. https://doi.org/10.1016/i.annals.2012.05.023

Song, H., \& Li, G. (2008). Tourism demand modelling and forecasting - a review of recent research. Tourism Management, 29(2), 203-220, https://doi.org/10.1016/j.tourman.2007.07.016

Smeral, E. (2015). Measuring the economic impact of tourism: the case of Lower and Upper Austria. Tourism Review, 70(4), 289297. https://ezlibrary.ju.edu.io:2057/10.1108/TR-01-2015-0002

Timothy, T., Cody Morris, P., Vernon, B. (2013). A Quantified TripleBottom Line for Tourism Experimental Results. Journal of Travel Research, 52(3), 279-293. https://doi.org/10.1177/0047287512465963

Tohmo, T. (2018). The economic impact of tourism in Central Finland: a regional input-output study. Tourism Review, 73(4), 521-547. https://ezlibrary.ju.edu.jo:2057/10.1108/TR-04-2017-0080

Tosun, C. (2002). Host erceptions of Impacts: A Comparative Tourism Study. Annals of Tourism Research, $29,231-253$. https://doi.org/10.1016/S0160-7383(01)00039-1

Wardana, I.M., Sukaatmadja, I.P.G., Yasa, N.N.K., \& Setini, M. (2020). Comparative and competitives advantages: perspective of rural tourism (study on tourism in the province of Bali Indonesia). GeoJournal of Tourism and Geosites, 33(4spl), 1493-1500. https://doi.org/10.30892/gtg.334spl07-598

Williams, J., \& Lawson, R. (2001). Community Issues and Resident Opinions of Tourism. Annals of Tourism Research, 28, 269-290. https://doi.org/10.1016/S0160-7383(00)00030-X

Wilson, D. (1997). Paradoxes of Tourism in Goa. Annals of Tourism Research, 24, 52-75. https://doi.org/10.1016/S0160-7383(96)00051-5 